\title{
From Islamist to Muslim Democrat: The Present Phenomenon of Muslim Politics in Malaysia
}

\author{
MOHD IZANI MOHD ZAIN ${ }^{1}$
}

\begin{abstract}
The Muslim political rivalry in democracy has triggered the birth of two groups; Islamist and Muslim Democrat. The two groups are competing by using a different approach in getting the support of the people. The Islamist group is championing its Islamic State agenda and the implementation of Shari'a as a political ambition within the framework of democracy while the Muslim Democrat recognises democracy and freedom as the basis of their struggle. Due to a greater development in democracy and a more open political rivalry, the Islamist group that was initially strongly backed by their rigid ideology and approach, has decided to change for a more moderate approach. This can be seen through their political strategy that emphasises on universal issues such as democracy, justice and good governance without rhetorical expressions of Islam and Shari'a. This change from Islamist to that of Muslim Democrat is an exciting development for it shows the transition path and direction of Muslim politics in Malaysia. This paper examines the latest development of the Islamist group, i.e. PAS in political rivalry in Malaysia, particularly in the recent General Election in 2013. This article reveals that due to the changing political landscape and democratization, the Islamist has pragmatically moderated their stance to gain more supports and it has embarked on a new landscape for Muslim political rivalry in Malaysia. Although PAS's new approach to transform its approach to be more open and democratic is still questionable, this study believes that the participation of the party in democracy is no longer just for the sake of election, on the other hand it should recognise democracy as a political culture that emphasizes justice, freedom and good governance.
\end{abstract}

Keywords: Islamist, Malaysian politics, Muslim Democrat, political coalition

Muslim Politics has seen a significant growth and transition in more than three decades ago. This development can be divided into three phases; the radical phase, the phase of democratization through elections and the consolidation phase of the democracy as a political culture. Since the current Islamic revival that swept the Muslim World, including Malaysia, which took place in the 1970's and later in the 1980's, Muslim Politics has demonstrated political rivalry between the ruling elite and the Islamic political movement or Islamist. According to Esposito (1996), the 1980's saw the Islamic political movement fighting for the political rights and aspirations of Islam through violence, conflict and tension. In this phase, democracy is still not accepted by the Islamic movement as it is considered a legacy of Western culture and, more importantly, it is immorally against the teachings of Islam when it (the democratization process) upholds mankind as the source of sovereignty.

\footnotetext{
${ }^{1}$ Mohd Izani Mohd Zain, M.A., Associate Professor, Dept. of Government and Civilization Studies, Faculty of Human Ecology, Universiti Putra Malaysia, 43400 SERDANG, Selangor Malaysia, email: eyerani@yahoo.com.
} 
The 80's is also seen as a dark era of Islamic Politics or Islamism because it is not only the inability of Islamist or the Islamist group to gain political power through election, but their failure to produce a new model of a desired society. Roy (1994) feels that the struggle of Islamic Politics at that time has proven that the reaction and protest is primarily against the failure of the Western system and the rhetoric to return to the teachings of Islam through the establishment of an Islamic State. Loud slogans such as advocating for Islamic State and antiWestern have become a norm for Islamic Politics without actually explaining the concept of an Islamic State in a clear and precise manner. The era of the rise of Islamic Politics, according to Roy is not happening and it has led to a cross path, either to become a modern and moderate political movement or through the evolution of the new fundamentalists who continue to fight for Sharia (Roy 2004).

The second phase, which took place in the following decade of the 1990's, witnessed a different scenario altogether when Islamic political movement began to embrace their acceptance for democracy and election. They realised that Islam is not lacking in terms of laying the foundation, which is parallel with the guidelines and goals of Islam (Haddad 1995). This development is also supported by the democratization process taking place in the world after the fall of communism. During this period, the Islamic movement has shown interest to accept and adapt the democratic process through election as a political platform, following the justifiable ideals in which they want to fight for the acceptance of Islam through a more open political participation (Kurshid Ahmad 2000). The acceptance of Islamic political movement via democratic process through election has fortified the struggle in paradigm shift from radical to a more moderate gesture (Mohd Izani 2005).

The participation of Islamic political movement in the democratic process through election has sparked a clash between the ruling elite and Islamist, in which some Islamist parties won in Algeria and Turkey. The victory of Front Islamique Salvation (FIS) and Refah has opened a new era for the survival of Islamic parties in democracy. However, the two Islamist parties failed to survive when they were deprived of the right to rule the country. This undemocratic action was taken on the claim that both FIS and Refah could threaten the scope of democracy itself in their endeavour and aspiration to establish an Islamic State government after winning the respective election. This development has raised some questions of whether Islam can co-operate or be compatible with the democratic system or otherwise. The 21st millennium has witnessed the changing landscape of world politics including the Islamic world, when the public at large began to rebel against autocratic leadership and started to demand a democratic government which recognizes human rights. Political discourse started to change at a very fast pace, thus leaving behind rhetoric of religion and Islamic State. More universal themes such as democracy, justice, freedom and good governance have gained a rightful place as each recognizes the rights of political participation in the nation. These developments also influence the Islamist group to better understand the political reality and its diversity thus forcing them to change to remain in political rivalry. The average Islamist groups have started to leave their old political discourse and strive to meet the demands and requirements of the people. This contrasts sharply with the rhetoric of Islamic State, which was proclaimed earlier, which is seen as a top-down approach and position the country as a power source.

The third phase (the consolidation phase of the democracy as a political culture) is the extension of phase two. This phase demands a greater commitment of democracy, which is not just about election but rather transforming democracy as a political culture (Tibi 2012). This phase has also witnessed how the Islamist group has finally agreed to adhere to democratic pluralism and religious diversity. Since the victory of the Justice and Development Party (AKP) in Turkey in 2002, it has introduced a model of a moderate and pragmatic Islamic party. Its focus on economic reform (and its success in driving economic growth in Turkey) and not merely a rhetoric of an Islamic State has uplifted the confidence of the people to continue to support the party for a second term in the 2007 election. The success of AKP in managing its 
participation in the democratic system in Turkey has been the focus of debates among observers of Islamic movements around the world. This includes making AKP as a comparative reference through its fresh approach in facing globalisation and diverse world so that they can be well received by the people, and no longer bound by the old-school thoughts which are deemed as conservative.

The paradigm shift and a shift towards a more tolerant approach are labelled as PostIslamism (Bayat 2011). Asef Bayat made this remark with the belief that political discourse has changed in tandem with the needs of Muslim universalism and no longer bound by the rhetoric of religion and Islam. He thinks that Post-Islamism is an ideology that is not important or not given proper attention in the Muslim political discourse nowadays. However, not many people are agreeable with his remark. Post-Islamism, which refers to the new discourse of Islamic Politics is questionable, whether it involves a change in ideology or just a change of strategy and approach (Lily Zubaidah 2011). This view is supported by Bassam Tibi (2012) who feels that if the Post-Islamism is the new political discourse that involves paradigm shift in terms of ideology and goals, the Islamist group must submit a new set of Islamic Politics. In fact, he believes that Post-Islamism is actually not the case because it only involves a change in approach and not the ideological shift of a bigger thing. In other words, the Islamist group has not abandoned the struggle for an Islamic State despite a moderate approach to strategic change. The study is not interested in continuing the discussion on post-Islamism because it is not the main focus in this paper. However it should be noted that whether Post-Islamism did occur or not, we must admit that there is indeed a change in the Islamist group's strategy that led to a new dimension in political rivalry. This particular change is interesting to study because it brings about a new dimension for Islamist political groups in particular and Muslims in general in a democratic system. As a result, democracy is no longer considered as contesting in election only, a channel to gain power legitimately, but a political culture that needs to be addressed seriously. In other words, democracy goes beyond the process of election.

The evolution of the three phases can be seen in Muslim Politics in Malaysia, even in a slightly different context. The 1980's saw the uprising tension between the government and the Islamist of the Pan Malaysian Islamic Party (PAS). This is due to the radical Islamic group's thoughts under the leadership of scholars (ulama) who are continuously fighting to uphold their ideology of a 'Muslim country' and the implementation of Islamic law in the country. The decade of the 1990's saw the rise of PAS by securing a bigger victory in the election, but the party still failed to capture the central government. Its success in taking over the government in Kelantan from Barisan Nasional (BN) has proven that the process of democratization has opened up a much better political participation in pursuing their Islamist agenda. Over the past decade, Muslim politics in Malaysia have shown some changes in their (Islamic group) approach towards democratization. Democracy is no longer viewed as merely taking part in election but instead has been more accepted as a political culture - which they have to be interactive in order to celebrate the diversity and human rights of the public. The third phase will be described in the last section of this article.

In comparison, the relationship between Islam and democracy in Malaysia is much better than the other Muslim countries - political rivalry involving the ruling elite and the Islamist group is more tolerable, both parties continue to work hand-in-hand although no doubt there are several challenges that need to be addressed. Political rivalry within the framework of democracy and election is always seen as the only avenue to obtain political power legally. In fact, as a result of the participation in the democratic process through election, PAS managed to form state government in Kelantan, Terengganu and Kedah and was able to establish the socalled Islamic government. At the same time, the party was able to carry out its role as an opposition based on its Islamic principles through their representative role in the House of Representatives or Parliament. 


\section{Competition between the Islamist and Muslim Democrat in Malaysia}

The competition to acquire political power through democratic process in the context of Muslim Politics has propelled the emergence of two groups. Among them, what Vali Nasr (2005) has labelled as the Islamist and Muslim Democrat. According to him, the Islamist is referred to as a Muslim movement who participates in the democratic process through election and aspires to establish an Islamic State. He claimed that Islamist is only using democracy as a tool to achieve political power. The second group of Muslim Democrat is seen in a more positive way, whereby this group participates in the democratic process to establish a stable country and capable of meeting the needs of the people without the influence of the rhetoric of the Islamic State or the implementation of Islamic law. According to Vali Nasr again, Muslim Democrat has a higher Muslim voters through its moderate approach, while the Islamist group often faces a conflict of interest, especially in the matter of sovereignty when they aspire to establish an Islamic State or the implementation of Islamic law. As a matter of fact, the Islamist's participation in democracy has raised some eyebrows because their victory in the election would undermine democracy itself. Even worse, they are denied the right to win for fear it could lead to the establishment of an Islamic State which eventually would resist the democratic system and also undermine secularism. In conclusion, the Islamist group is not suitable to participate in democracy.

In Malaysia, competition among Muslim Politics is normally centred between two political parties, which is Malay-centric and Islamic in nature UMNO and PAS. UMNO or the United Malays National Organization was established in 1946, as a result of its continuous fight in opposing the formation of Malayan Union, particularly in protecting the interests of the Malays and Islam. Although UMNO was established to safeguard the affairs of the Malays and Muslims in the country, UMNO is very pragmatic in its approach and able to work with other component parties within the Alliance and later Barisan Nasional (BN). In this context, UMNO is seen as a group of moderate and pragmatic Muslim Democrat in its approach and in support of the framework of democracy and not be influenced by the rhetoric of the Islamic State and the implementation of Islamic law.

The second group, i.e. the Islamist is represented by PAS. The party, which was established in 1951 has a strong commitment to establish an Islamic State (Muhammad Syukri 1999) in which Islam would become the faith (official religion) of the country, imbued in the Constitution and national legislation, and encapsulating all systems in the country (Ibrahim Abu Bakar 1993). Although the party has always wanted to establish an Islamic country, it plans to do it within the democratic framework. PAS has stated its commitment to promote democracy since its inception. Through its third annual conference in Kepala Batas on January 4, 1953, the party has put forward a number of goals that must be dealt with, and among them, 'strive harder to introduce a true democracy in order to benefit the nation and the Muslims and will try to instil the spirit of democracy into their souls, and eventually showing the ways to achieve democracy' (Alias 1984).

In the aftermath of the country's leadership crisis in 1998, the political landscape in Malaysia is becoming more open, and influenced by a new political discourse has uplifted democracy, justice, freedom and good governance as a priority, over the ideological Islamic State. In anticipation of this, the Islamist group has decided to change their approach and become more tolerant to embrace the current political reality. They need to change or if not, will be marginalized in the mainstream political competition. This article will focus on the development of the Islamist group in the context of Muslim Politics in Malaysia and the paradigm shift approach in creating new methods in facing political turmoil in the country. 


\section{From Islamist to Muslim Democrat: PAS in the General Election 2013}

PAS is the only opposition party that has remained in political rivalry in Malaysia since the first general election in 1955. Many political parties have died because of lack of support from the people including Parti Negara and Parti Melayu Semangat 46. So this is where PAS has an advantage because it can adapt to climate change through the changing political strategy despite the fact that some people are actually in doubts of their sincerity. Starting with its IslamicNationalism from 1950 to 1970 which focuses on fundamentalism and leadership scholars (ulama) approach to an open door policy in the 90's through political cooperation with the Democratic Action Party (DAP), clearly explained that its political approach continues to change in order to maintain their survival in political rivalry in Malaysia. Although at that time PAS continued to fight for the establishment of an Islamic State, the change in its approach has proven that the party will not take for granted the political landscape changes that are taking place.

The crisis leadership of the country in 1998 has opened a new chapter in Malaysian politics. At that point, PAS as a political party has indeed grown up, and gained some political mileage and became more vocal in demanding for a truly democratic government and justice in the country. From an opposition party that could only capture the state of Kelantan, PAS is now a major supporter of the opposition, at that time known as Barisan Alternatif (BA). Thus began a new era for PAS in fighting for a political discourse which is more receptive and appreciative of diversity. Although its submission of the Islamic State Document in 2003 for the upcoming election was considered its biggest mistake ever, thus causing poor performance in the general election in 2004, PAS is now more careful when using political tools and becoming more closer to the people. This approach can be seen until now, especially during the general election in 2013. In the election, PAS performed well and was able to maintain its momentum by getting more popular votes by almost half a million votes of 492,791 votes, compared to the general election in 2008. In total, the popular votes obtained by PAS were 1,633,389 votes. However, it is still considered lower than that achieved by its partners in the Pakatan Rakyat (PR), Parti Keadilan Rakyat and DAP. In addition, the number of parliamentary seats dropped two seats to 21 seats compared to 23 seats in 2008. However, PAS managed to add two more seats in the State Assembly, making it a total of 85 seats in 2013. PAS continues to rule in Kelantan as well as receives increasing support in Selangor and Terengganu but lose Kedah to Barisan Nasional (BN). The popular votes achieved by PAS for Parliament Seats in the general election (see Table 1):

\begin{tabular}{|ccc|}
\hline Year & Popular Votes & Percentage (\%) \\
1990 & 338,340 & 6.72 \\
1995 & 437,022 & 7.31 \\
1999 & 994,279 & 15.0 \\
2004 & $1,051,480$ & 15.2 \\
2008 & $1,140,598$ & 14.4 \\
2013 & $1,633,389$ & 14.51 \\
\hline
\end{tabular}

Table 1: Popular Votes Achieved by PAS for Parliament Seats in the General Elections

PAS's achievement in the general election in 2013 is a result of their approach towards tolerance in political strategy and their understanding of the current political reality. The approach and strategy can actually be seen since the 1999 general election, but is further strengthened and streamlined in lieu of the experience and political challenges that they face. The party's achievements in the general election in 2013 can be summarized in three main 
contexts, namely 'Political Discourse of Democracy', 'Power Sharing' and 'Inclusive Policy or Inclusiveness'.

\section{Political Discourse of Democracy}

PAS realised that they failed to convince the majority of the ideology and the establishment of an Islamic State and the implementation of Islamic law. The campaign for an Islamic State and the Islamic State Document that was launched in 2003 has been the cause of the defeat of the party in the general election in 2004 (Drakeley 2008). In relation to that, PAS wants to get rid of the radical image and instead diverts its focus on issues which are closer to the people such as democracy, justice and good governance. Through its pact with PKR and DAP in the political cooperation through Pakatan Rakyat, the issue of establishing an Islamic State and Islamic law is no longer the priority, especially for the purpose of winning the election.

As Malaysia is a plural society, the creation of an Islamic State and the implementation of Islamic law is not a priority. As proven, the rhetoric of Islam and 'hudud' law are no longer included in the 2013 General Election Manifesto of Pakatan Rakyat, but the emphasis is more on the recognition of Islam as the official religion and the guarantee of freedom of religion for nonMuslims as enshrined in the Federal Constitution. More importantly, the Kelantan PAS manifesto entitled "Prosperity and Welfare", encompassing nine main criteria also did not mention about the Islamic State and 'hudud' law. However, PAS President, Abdul Hadi Awang said the implementation of 'hudud' should not be interpreted in detail, but adequately mentioned to prevent sinful activities based on Sharia law, which is considered as fair (Anon. 2011). Meanwhile, PAS vice-president Husam Musa felt that PAS should be able to distinguish what are the priorities that need to be addressed before and after acquiring the power. He said: "So if we place our emphasis on certain areas, and ignoring other aspects, it is detrimental to the fight (struggle) itself. So how we position our focus is important and what we can do before we are in power is another matter, and what we can do after that is another matter". Undoubtedly, the transition in PAS's approach in fighting for an Islamic State on issues of democracy, justice and good governance has been successful, and to some extent 'dilute' their ambition over the years to establish an Islamic State and the implementation of Islamic law. It is also open to criticism that the party is not pressing hard on issues affecting the interests and sovereignty of Islam. PAS allegedly bowed to the pressure and influence of liberalism and pluralism. The most controversial issue is when PAS and PR have both agreed that the word 'Allah' can be used by Christians as long it is not abused. This stance has raised intra-party conflict, particularly from PAS deputy president, Haron Din, who had asked the party leaders to withdraw the decision and insisted that the support given in the use of the word 'Allah' amongst non-Muslims could lead to polytheism.

\section{Power Sharing}

PAS believes that to compete in democratic politics which has becoming increasingly competitive in Malaysia, it should accept and participate in the sharing of power. This means that PAS can no longer move alone even if the party is the only opposition party that managed to survive since the first election in 1955. Accordingly, PAS had a political partnership with DAP, Parti Keadilan Rakyat (PKR) and Parti Rakyat Malaysia (PRM) in Barisan Alternatif in 1999 and then Pakatan Rakyat in 2008. PAS has an advantage through this political coalition and this is reflected in the increase in voters support in the election, including from non-Muslims/nonMalays. Earlier, PAS had worked with Parti Melayu Semangat 46 by forming Angkatan Perpaduan Ummah (APU). However, this political cooperation is strictly based on political interests amongst the Malays/Muslims and did not involved non-Muslim cooperation, as in Barisan Alternatif and PR. 
In this case, PAS cannot run away from all sorts of criticism because of its political cooperation or tahaluf siyasi with other opposition parties. The influence of PAS in Pakatan Rakyat is weakening despite an increase in public support. In other words, PAS is not a leader but merely a follower in PR. Recently, the 'Multaqa Ulama Se-Malaysia' held at Kedah PAS Complex has reached some resolutions and suggested that tahaluf siyasi between PAS and its allies in the opposition, especially Parti Keadilan Rakyat (PKR) should be reviewed. According to the Assistant Secretary of the PAS Ulama Council, Muhammad Ismi Mat Taib, the review or audit of the implementation of this tahaluf siyasi is based on a number of issues as follows - the allocation of seats among PR component parties does not give much value to the strengthening of the position and influence of PAS in PR, there were cases of PAS members contesting under PKR banner after relinquishing their membership in PAS, members and leaders alike in PAS who did not perform thiqah and wala' to the congregation but instead prefer to listen to the decisions and directions from outsiders, PAS members and leaders who liked to issue statements and views which contradict the teachings of Islam while some tried to inculcate explicit notion of pluralism and liberalism, and the decline in Malay support for PAS compared to GE12 which is the era before the existence of PR (Muhammad Ismi 2013).

This view has its justification when viewed in the context of the votes of the Malays when PAS failed to defend the state of Kedah in the general election in 2013. PAS managed to secure only 9 seats of the State Assembly (DUN) from the 16 seats that they won in the general election in 2008. Apart from that, the support for PAS in Kelantan had also dropped; it won 32 seats compared with 37 in the previous general election. On the other hand, PAS managed to increase the number of seats in the state of Selangor, Johor and Pahang. This means that PAS managed to increase non-Malay support but failed miserably when it comes to support from Malays/Muslims.

In response to the resolution of the 'Multaqa Ulama Se-Malaysia', PAS top leaders felt that the revised proposal of the tahaluf siyasi would definitely strengthen political cooperation between PAS and others in Pakatan Rakyat and thus decided not to distance themselves of the cooperation. In other words, PAS still believes and will continue with its tahaluf siyasi in ensuring the survival of their political future. This stance can be clearly seen during the $59^{\text {th }}$ PAS Muktamar in November 2013 when PAS duly agreed to remain in political cooperation through PR.

\section{Inclusive Policy or Inclusiveness}

Apart from changing its approach - from emphasizing on the establishment of an Islamic State towards democracy, justice and good governance and political cooperation, PAS has also introduced a more inclusive policy to gain support from more people of all backgrounds and non-Muslims in particular by launching the slogan 'PAS for All' in 2007. This move was taken because PAS did not want to be seen as an exclusive party for a specific group such as religious groups and those in rural areas only. Since the 90's, PAS has been accepting professionals who are receptive towards the party's struggle. Now, PAS is not only supported by the party members, but those who come from various backgrounds including young people, NGO activists and community leaders.

At the same time, to win non-Muslims support, PAS has established PAS Supporters Club in 2004 which was later upgraded to Non-Muslim Supporters Assembly, in 2010. For the first time in history, PAS has fielded the chief of PAS Supporters Congress (PSC), Hu Pang Chow as a candidate for the Ayer Hitam Parliament seat in Johor in the last general election in 2013. In the general election of 2008, PAS has also fielded a non-Muslim candidate, Kumutha Rahman, who is also from PSC but contested under the PKR banner. According to Mujahid Yusuf Rawa, Member of Parliament of Parit Buntar and Chairman of Lajnah Unity of PAS, the success that they achieved in securing the support of non-Muslims through the PSC undoubtedly help PAS to 
elevate its aspiration to be a multi-ethnic party. The ball is in their hands, thus, it is indeed favourable for the party to no longer rely on the assistance of other parties in PR such as DAP and PKR in order to get non-Muslims support in the election (Mujahid 2012).

Undoubtedly, the policy of inclusivity or inclusiveness provides a positive image to PAS but at the same time, becomes a test and a burden for the party because they have to manage a diversity in views. Immediately after the 13 th general election, statements made by some PAS leaders who did not support street demonstrations in dispute of the outcome of the election, received unfavourable response and feedback from some party supporters in the social media. In this regard, the Deputy Chief Minister of Kelantan, Mohd Amar Nik Abdullah had made it clear that he did not endorse any street demonstrations that cause more harm to the country. Instead, he called on Malaysians, including supporters of the party and Pakatan Rakyat, especially PAS in general to respect the election results of the 13th general election with an open mind. Mohd Amar's statement was supported by several other PAS leaders including PAS Ulama Council chief Harun Taib and deputy PAS Youth chief Nik Mohd Abduh Nik Abdul Aziz, who recently urged all parties to accept the results of the $13^{\text {th }}$ general election which saw the Barisan Nasional (BN) continued to be given the mandate to rule the country.

This remark is disrespectful to the people's support for PAS all this while. The party is reminded to continue fighting together with its supporters, especially the non-party members, NGOs and young people who helped the party to win in the last election in 2013. Without a doubt, PAS's victory in the last general election is not mainly because of party members, but also supporters of non-party members and activists of non-governmental organizations (NGOs) who were not in favour of the government party.

\section{Transition of Islamist to Muslim Democrat: Trend or Eternal Change/Evolution?}

Changes in the political landscape of the country and the rising political rivalry has affected the approach and strategy of the Islamist group. They have no other options but to change or be marginalized from mainstream politics. Indeed, the approach in the 80's and 90's cannot be practiced in the present political landscape which is more open and flexible. Their new platform is no longer based on the rhetoric of Islamic State or top-down approach, but more towards bottom-up approach which celebrates democracy, justice and freedom. The change in approach by the Islamist group has opened a new platform in political rivalry. For Nasr (2005), this change has obscured the original identity of the Islamist and the Islamist group's transformation into a Muslim Democrat which is more compatible and in line with democracy and its demands. This is actually not an impossible thing to happen because the Muslim Democrat could also emerge from the transition of the Islamist group.

The general election of 2013 showed that PAS could maintain a tolerant approach and a more open political discourse compared to the previous election. What is clear, no more rhetoric of Islamic State and the implementation of hudud law in the election manifesto but rather focusing on uplifting the aspirations of the Islamic faith as the official religion as enshrined in the Federal Constitution. This is also part of the process of rejuvenation or rebranding of PAS in order to further consolidate its position as a national party (Mujahid 2012). It will also be seen as a serious effort undertaken by the party to face the next general election by securing better results.

The trends and new routes of the Islamist group in political rivalry is expected to continue, especially if we relate it to the third phase of expansion of Muslim Politics and democracy as stated earlier in this paper. However, it should be noted that these changes are going through difficult time. This is because it still cannot get away from the ultimate question, whether PAS can still maintain its moderate and democratic approach? This question remains in perspective and is particularly relevant if we look at the latest developments of the Kelantan State Government who wants to implement the hudud law and present a proposal to implement 
the law in Parliament in June 2014. Though PAS later withdrew this proposal and agreed to make room for the Technical Committee to be set up and to submit the proposed action plan towards the implementation of the Syariah Criminal Code (II) 1993 for the State of Kelantan, PAS insists that it will continue to implement the hudud law in the future.

Although PAS's new approach to transform its approach to be more open and democratic is still questionable, this study believes that the participation of the party in democracy is no longer just for the sake of election, on the other hand it should recognise democracy as a political culture that emphasizes justice, freedom and good governance. The change in the Islamist group's strategy with a more realistic approach not only opens up new routes and platform for them in political rivalry, but also brings the relationship of Islam and democracy to a greater extent of tolerant and pragmatic.

\section{References}

Alias Mohamed. 1984. PAS Platform: Development and Change: 1951-1986. Kuala Lumpur: Gateway Publishing House Sdn. Bhd.

Anon. 2011. Berita Harian, 8 December.

Bayat, Asef. 2011. The Post Islamist Revolution. New York: Council on Foreign Relations.

Drakeley, Steven. 2008. Drowning or waving: Citizenship, multiculturalism and Islam in Malaysia. Al-Jami'ah 46(2): 326-352.

Esposito, J. L. 1996. Islam dan Democracy. New York: Oxford University Press.

Haddad, Y.Y. 1995. Islamists and the Challenge of Pluralism. Washington: Georgetown University.

Ibrahim Abu Bakar. 1993. Perbandingan pemikiran politik agama PAS dan UMNO. In. Wan Hashim Wan Teh (ed.). UMNO dalam Arus Perdana Politik Kebangsaan. Kuala Lumpur: Penerbit Mahir Publications Sdn. Bhd.

Kurshid Ahmad. 2000. Islam and democracy: Some conceptual and contemporary dimensions. The Muslim World 90(1\&2): 1-21.

Lily Zubaidah Rahim. 2011. Towards a post-Islamist secular democracy in the Muslim world. Paper for the Contemporary Challenges of Politics Research Workshop. Crowne Plaza Hotel Coogee Beach. New South Wales.

Muhammad Ismi Mohd Taib. 2013. Tahaluf Siyasi: Jauhi Sensasi dan Kontroversi. http://bm.harakahdaily.net/index.php/berita-utama/22220-tahaluf-siyasi-jauhkansensasi-dan-kontroversi. [1 November 2013].

Muhammad Syukri Salleh. 1999. Establishing an Islamic state: Ideals and realities in the state of Kelantan, Malaysia. Journal of Southeast Asian Studies 37(2): 235-256.

Mujahid Yusof Rawa. 2012. Rejuvenasi PAS: Idea, Realiti, Aplikasi ke arah Aspirasi Masa. Kuala Lumpur: Ilham Centre.

Mohd Izani Mohd Zain. 2005. Islam dan Demokrasi: Cabaran Politik Muslim Kontemporari di Malaysia. Kuala Lumpur: Penerbit Universiti Malaya.

Nasr, Vali. 2005. The rise of Muslim democracy. Journal of Democracy 16(2): 13-27.

Roy, Oliver. 1994. The Failure of Political Islam. Cambridge: Harvard University Press.

Roy, Oliver. 2004. Globalized Islam: The Search of New Ummah. New York: Columbia University Press.

Tibi, Bassam. 2012. Islamism and Islam. New Haven \& London: Yale University Press. 